\title{
Wind Power Management using IoT and Wi-Fi
}

\author{
V. Jayalakshmi, K. Sakthivel, S. Sherine
}

\begin{abstract}
As the call for wind power keeps on creating at exponential rates, decreasing activity and redesign costs and improving unwavering quality have come to be zenith needs in wind Mill(WM) upkeep methods. additionally to the improvement of more prominent very created WM plans expected to improve accessibility, the utilization of dependable and cost compelling circumstance observing (CM) procedures offers a green strategy to accomplish this goal.among those exceptional systems temperature,oil degree following and voltage detecting is a principle job. The center objectives of this proposed remote wellness checking frameworks are to find the common wellness circumstance of the framework, to avert debacles brought about by mechanical and electrical flaws, to anticipate the seriousness phase of issue, and to assess the valuable existence of the gadget utilizing net. [19],[20],[21]
\end{abstract}

Keywords : ATmega328, Wifi, Temperature sensor, Oil level sensor, Oil condition sensor, Voltage sensor, Vibration sensor.

\section{INTRODUCTION}

The internet of things (IoT) is the community of bodily gadgets or matters embedded with electronics, software, sensors and network connectivity which permits those gadgets to accumulate and exchange statistics. The internet of factors permits gadgets to be sensed and managed remotely throughout existing network infrastructure, developing possibilities for more direct integration between the physical global and pc-based systems, and resulting in improved efficiency, accuracy and monetary benefit. except the pleothra of recent application regions of internet related automation to increase into, IoT is predicted to generate massive quantity of records from various locatiob i.e. aggegrated right away,thereby growing the need to better index, shop and procedure such information. [14],[ 16], [18]

\section{WIND POWER MANAGEMENT USING IOT AND WIFI}

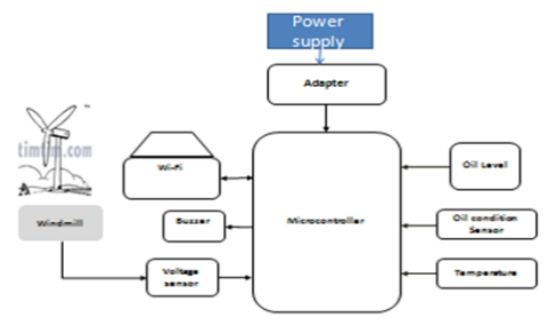

Figure 1 Wind power management system

It contains ATmega 328 microcontroller, oil level sensor

Revised Manuscript Received on August 22, 2019.

Dr.V.Jayalakshmi, Associate Professor Department of EEE,Bharath Institute of Higher education and research, Tamilnadu, India.

K.Sakthivel Assistant Professor Department of EEE,Bharath Institute of Higher education and research, Tamilnadu, India.

S.Sherine, Assistant Professor Department of EEE,Bharath Institute of Higher education and research, Tamilnadu, India which detects the level of oil present over there, oil condition sensor which detects the thickness of the oil, temperature sensor which detects the temperature of the windmill, voltage sensor which detects the voltage level, wi-fi to connects and monitor the windmill and also buzzer which beeps whenever fault occurs. So the main function of this system is to detect fault by using IoT and wifi which reduces man power.
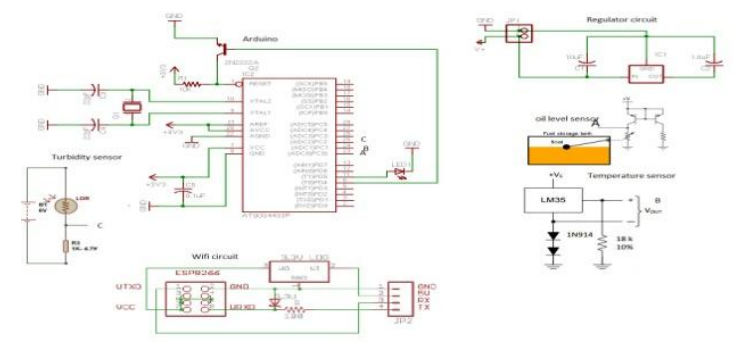

Figure 2 Circuit diagram of wind power management system

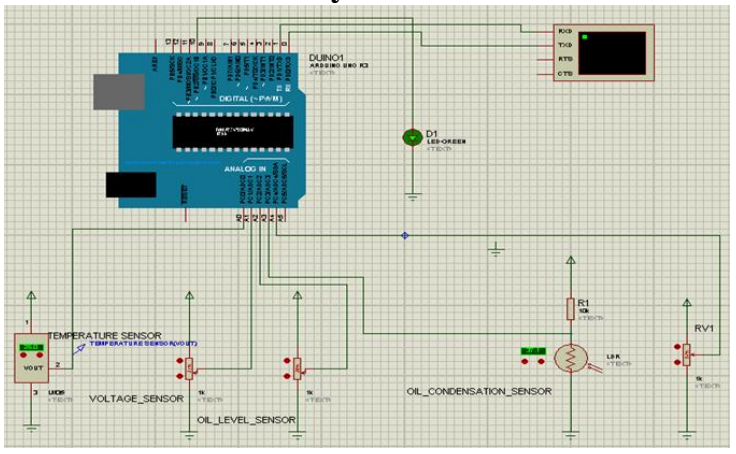

Figure 3 Simulation circuit of wind power management system

In our project we develop a smart network by using Wi-Fi and internet. The purpose of networking is to know the overall power available and fully automated windmill monitoring ,to prevent failures caused by mechanical and Electrical faults and to predict the severity level of fault. [13], [15] , [17]

First we will give $5 \mathrm{v}$ power supply to the arduino kit then we will connect temperature sensor to A0, voltage sensor at $\mathrm{A} 1$, oil level sensor at $\mathrm{A} 2$, oil condition at A3, vibration sensor to A4, ESP8266 Wifi at $8^{\text {th }} \& 9^{\text {th }}$ pin and buzzer at $11^{\text {th }} \& 12^{\text {th }}$ pin. [8],[10],[12]

We will see the output through wifi on internet. On thingspeak website we can check the condition of each parameters at time to time.

After giving proper connections,we will upload the program in the arduino kit which contain the API key, range of each parameters are also declared 
in the program. So whenever any fault occurs in the windmill then the buzzer beeps. [7],[ 9], [11]

\section{RESULT AND DISCUSSION}

\section{A. TEMPERATURE SENSOR}

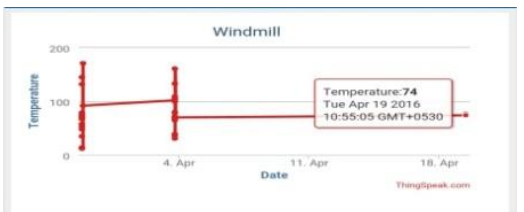

Figure 4 temperature sensor

The Figure 4 shows the graph for temperature sensor. It is the output of the temperature sensor which varies time to time according to the temperature it get.It will show values in the form of ADC[2 ],[4],[6]

\section{B. OIL CONDITION SENSOR}

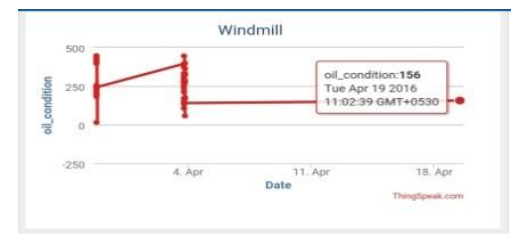

Figure 5 Oil condition sensor

The Figure 5 shows the graph for oil condition sensor. It is the output of the oil condition sensor which varies time to time whenever the oil gets contaminated.It will show values in the form of ADC.

\section{OIL LEVEL SENSOR}

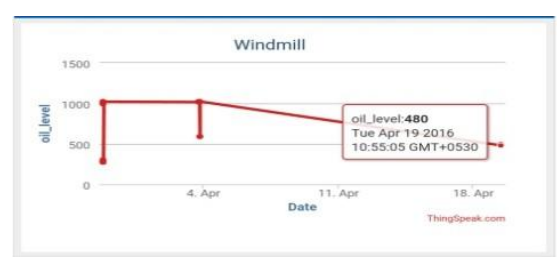

Figure 6 Oil level sensor

The Figure 6 shows the graph for oil level sensor. It is the output of the oil level sensor which varies time to time when the level of the oil is varied.It will show values in the form of ADC.

\section{VOLTAGE SENSOR}

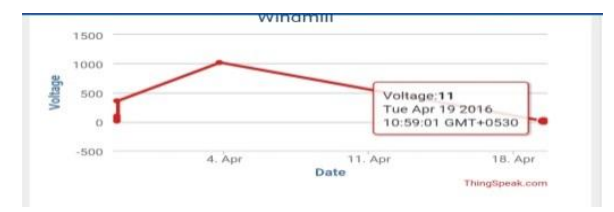

Figure 7 voltage sensor

The Figure 7 shows the graph for voltage sensor. It is the output of the voltage sensor which varies time to time when the voltage gets fluctuated.It will show values in the form of ADC.

\section{E. VIBRATION SENSOR}

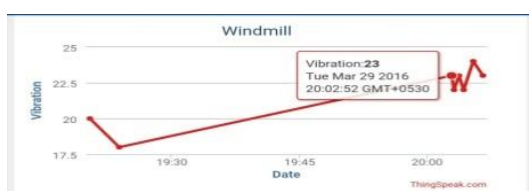

Figure 8 Vibration sensor

The Figure 8 shows the graph for vibration sensor. It is the output of the vibration sensor which varies time to time when any kind of vibration occurs in the windmill.It will show values in the form of ADC. [1],[3],[5]

\section{CONCLUSION}

The mechanical and electric failure is the maximum serious trouble faced within the wind mills. greater touchy areas like gears and turbines are extra vulnerable to faults that are the foremost reasons to have an effect on the production of wind turbine. The device fitness monitoring that is proposed here is greater crucial aspect that to mentioned.

\section{REFERENCES}

[1] Sharma, R.K., Irusapparajan, G. \& Periyaazhagar, D. 2019, "Three-phase symmetric cascading Z-source seven levels multilevel inverter excited by multi carrier sinusoidal pulse width modulation scheme", International Journal of Innovative Technology and Exploring Engineering, vol. 8, no. 10, pp. 4269-4274.

[2] Velavan, R., Bharanidharan, S. \& Sheeba, B. 2019, "EMF pollution Causes, effects and protection", International Journal of Innovative Technology and Exploring Engineering, vol. 8, no. 9 Special Issue 3, pp. 1166-1168.

[3] Saravana, S., Balaji, S., Arulselvi, S. \& John Paul Praveen, A. 2019, "Reliable power quality monitoring and protection system", International Journal of Innovative Technology and Exploring Engineering, vol. 8, no. 9 Special Issue 3, pp. 644-645.

[4] Tamil Selvan, S. \& Sundararajan, M. 2019, "Performance Parameters of 3 Value 8t Cntfet Based Sram Cell Design Using H-Spice", International Journal of Recent Technology and Engineering, vol. 8, no. 2 Special issue 5, pp. 22-27.

[5] Jac Fredo, A.R., Abilash, R.S., Femi, R., Mythili, A. \& Kumar, C.S 2019, "Classification of damages in composite images using Zernike moments and support vector machines", Composites Part B Engineering, vol. 168, pp. 77-86.

[6] Kathiravan, P. \& Govindaraju, C. 2019, "Design and evaluation of ultra gain isolated DC-DC converter for photovoltaic system", International Journal of Engineering and Advanced Technology, vol. 8, no. 5, pp. 2646-2651.

[7] Kripa, N., Vasuki, R. \& Kishore Kanna, R. 2019, "Realtime neural interface controlled au-pair BIMA bot", International Journal of Recent Technology and Engineering, vol. 8, no. 1, pp. 992-994.

[8] Mohanraj, Meenaa Kumari, M., Philomina, S. \& Jasmin, M. 2019 "In-situ humidity measurement of hydrogen fuel cell car using MEMS sensor", International Journal of Recent Technology and Engineering, vol. 8, no. 1, pp. 41-43.

[9] Velmurugan, T. \& Prakash, S. 2019, "Artificial intelligent based distribution automation of swift fault detection isolation and power restoration for HT network", International Journal of Innovative Technology and Exploring Engineering, vol. 8, no. 6, pp. 1-6.

[10] Dwarakesh, K. \& Prem Kumar, G. 2019, "Five-level inverter based sequential boost system using fuzzy logic controller", International Journal of Innovative Technology and Exploring Engineering, vol. 8, no. 6, pp. 12-19.

[11] Anne Gifta, A. \& Hemavathi, G. 2019, "Analysis of grid tied solar PV system using ANFIS Algorithm", International Journal

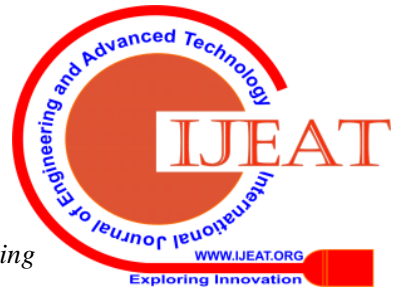


of Innovative Technology and Exploring Engineering, vol. 8, no. 6, pp. 312-316.

[12] Jayavel, R., Rangaswamy, T.R. \& Prakash, S. 2019, "Efficient grid management system with renewable and conventional power sources", International Journal of Innovative Technology and Exploring Engineering, vol. 8, no. 6, pp. 287-289.

[13] Hemavathi, G. \& Maheshwaran, S. 2019, "Proportional resonant controlled high gain step-up converter system with improved response", International Journal of Innovative Technology and Exploring Engineering, vol. 8, no. 6, pp. 317-323.

[14] Periyaazhagar, D. \& Irusapparajan, G. 2019, "Design and completion of asymmetric single phase 27 level cascaded mli for various pwm scheme", International Journal of Innovative Technology and Exploring Engineering, vol. 8, no. 6, pp. 792-797.

[15] Mahalakshmi, V. \& Vijayaragavan, S.P. 2019, "PV based power electronic converters for high voltage DC applications", International Journal of Recent Technology and Engineering, vol. 7, no. 6, pp. 670-674.

[16] Irusapparajan, G., Periyaazhagar, D., Prabaharan, N. \& Rini Ann Jerin, A. 2019, "Experimental verification of trinary DC source cascaded h-bridge multilevel inverter using unipolar pulse width modulation", Automatika, vol. 60, no. 1, pp. 19-27.

[17] Sangeetha, G., Sherine, S., Arputharaju, K. \& Prakash, S. 2019, "On Line Monitoring of Higher Rated Alternator using Automated Generator Capability Curve Administer", Proceedings of the IEEE International Conference on \&amp;quot;Recent Trends in Electrical, Control and Communication\&amp;quot;, RTECC 2018, pp. 176.

[18] Bycil, V.J. \& Wiselin, M.C.J. 2019, "Modeling and analysis of vibration energy harvesting system using piezo stack", International Journal of Mechanical and Production Engineering Research and Development, vol. 9, no. Special Issue 1, pp. 523-533.

[19] Sripada, A., Warrier, A., Kapoor, A., Gaur, H. \& Hemalatha, B. 2018 , "Dynamic lateral balance of humanoid robots on unstable surfaces", International Conference on Electrical, Electronics, Communication Computer Technologies and Optimization Techniques, ICEECCOT 2017, pp. 539.

[20] Srinivasan, S., Thirumalaivasan, K. \& Sivakumaran, T.S. 2018 , "Performance evaluation of double-output luo converters", Journal of Advanced Research in Dynamical and Control Systems, vol. 10, no. 10 Special Issue, pp. 870-878.

[21] Karthikayen, A. \& Selvakumar Raja, S. 2018, "A skellam distribution inspired trust factor-based selfish node detection technique in MANETs", Journal of Advanced Research in Dynamical and Control Systems, vol. 10, no. 13, pp. 940-949.

\section{AUTHORS PROFILE}

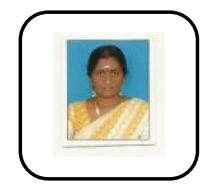

Dr.V.Jayalakshmi*, Associate Professor Department of EEE,Bharath Institute of Higher education and research, Tamilnadu, India.

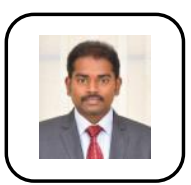

K.Sakthivel Assistant Professor Department of EEE,Bharath Institute of Higher education and research, Tamilnadu, India.

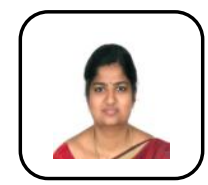

S.Sherine, Assistant Professor Department of EEE,Bharath Institute of Higher education and research, Tamilnadu, India 